\title{
Peritoneal adhesion index (PAI): proposal of a score for the "ignored iceberg" of medicine and surgery
}

\author{
Federico Coccolini ${ }^{1 *}$, Luca Ansaloni ${ }^{1}$, Roberto Manfredi ${ }^{1}$, Luca Campanati ${ }^{1}$, Elia Poiasina ${ }^{1}$, Paolo Bertoli ${ }^{1}$, \\ Michela Giulii Capponi ${ }^{1}$, Massimo Sartelli ${ }^{3}$, Salomone Di Saverio ${ }^{4}$, Michele Cucchi ${ }^{2}$, Daniel Lazzareschi ${ }^{1}$, \\ Michele Pisano ${ }^{1}$ and Fausto Catena ${ }^{2}$
}

\begin{abstract}
Peritoneal adhesions describe a condition in which pathological bonds form between the omentum, the small and large bowels, the abdominal wall, and other intra-abdominal organs. Different classification systems have been proposed, but they do not resolve the underlying problem of ambiguity in the quantification and definition of adhesions. We therefore propose a standardized classification system of adhesions to universalize their definition based on the macroscopic appearance of adhesions and their diffusion to different regions of the abdomen. By scoring with these criteria, the peritoneal adhesion index (PAI) can range from 0 to 30, unambiguously specifying precise adhesion scenarios. The standardized classification and quantification of adhesions would enable different studies to more meaningfully integrate their results, thereby facilitating a more comprehensive approach to the treatment and management of this pathology.
\end{abstract}

Keywords: Adhesions, Classification, PAl, Peritoneal, Abdominal, Occlusion, Surgery, Treatment, Prevention

\section{Article}

Peritoneal adhesions are pathological bonds that typically form between the omentum, the small and large bowels, the abdominal wall, and other intra-abdominal organs. These bonds may be a thin film of connective tissue, a thick fibrous bridge containing blood vessels and nerve tissue, or a direct adhesion between two organ surfaces [1-3].

Depending on the etiology, peritoneal adhesions may be classified as congenital or acquired (post-inflammatory or post-operative) [4]. Some researchers assert that adhesions could also be classified in three major groups: adhesions formed at operative sites, adhesions formed de novo at non-operative sites, and adhesions formed after the lysis of previous adhesions [5]. Diamond et al. distinguished types 1 and 2 of postoperative peritoneal adhesions. Type 1 , or de novo adhesion formation, involves adhesions formed at sites that did not have previous adhesions,

\footnotetext{
* Correspondence: federico.coccolini@gmail.com

'General and Emergency Surgery department, Papa Giovanni XXIII hospital, Piazza OMS-Organizzazione Mondiale della Sanità 1, 24128 Bergamo, Italy Full list of author information is available at the end of the article
}

including Type 1A (no previous operative procedure at the site of adhesion) and Type $1 \mathrm{~B}$ (previous operative procedures at the site of adhesion). Type 2 involves adhesion reformation, with two separate subtypes: Type 2A (no operative procedure other than adhesiolysis at the site of adhesion) and Type 2B (other operative procedures at the site of adhesions) [6]. In 1990, Zhulke et al. proposed a classification of adhesions based on their macroscopic appearance, which has since been used expressly for experimental purposes [7]. These different classifications have no impact on the underlying problem of post-operative/ post-inflammatory adhesions, which can be dramatic. Moreover these classification systems do not engender an unequivocal system of quantification and definition. Each surgeon defines adhesions on an individual basis contingent on the surgeon's own experience and capability. At present, it is not possible to analytically standardize adhesions, even if such cases are a surgeon's primary focus. The prevalence of adhesions following major abdominal procedures has been evaluated to be $63 \%-97 \%$ [8-12]. Laparoscopic procedures compared to open surgery have not demonstrated to significantly reduce the total number 
of post-operative adhesions [13-17]. Adhesions are a major source of morbidity and are the most common cause of intestinal obstruction $[18,19]$, secondary female infertility, and ectopic gestation $[20,21]$. They may also cause chronic abdominal and pelvic pain $[3,22,23]$. Adhesive small bowel obstruction is the most serious consequence of intraabdominal adhesions. Colorectal surgery has proven to be the most common surgical cause of intra-abdominal adhesions. Among open gynecological procedures, ovarian surgery was associated with the highest rate of readmission due to subsequent adhesions (7.5/100 initial operations) [24]. Retrospective studies have shown that $32 \%-85 \%$ of patients who require secondary abdominal surgery have adhesion-related intestinal obstruction. Experimental and clinical studies are not in agreement regarding the different rates of adhesion reformation following adhesiolysis performed via laparotomy or laparoscopy [25-27].
Guidelines have been published regarding the management of adhesive small bowel obstruction by the World Society of Emergency Surgery (WSES) [28].

Adhesions require highly involved surgical intervention and are a significant burden to health care systems. In the United States, an epidemiological study demonstrated that in 1988, 282,000 hospital admissions were attributable to adhesion-related disorders, and the cost of in-patient adhesiolysis procedures reached $\$ 1.18$ billion [29]. Another study published in 1994, reported that $1 \%$ of all admissions in the United States involved adhesiolysis, costing \$1.33 billion [30]. Adhesions and their associated complications have piqued both medical and legal interest in recent years [31]. Successful medical/legal claims include cases of bowel perforation following laparoscopic resolution of adhesion, delays in the diagnosis of adhesion obstruction of the small bowel, infertility resulting from

\section{PERITONEAL ADHESION INDEX:}

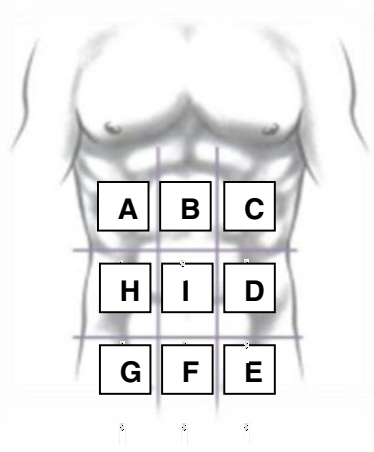

Regions: Adhesion grade: Adhesion grade score:

A Right upper
B Epigastrium
C Left upper
D Left flank
E Left lower
F Pelvis
G Right lower
H Right flank
I Central
L Bowel to bowel

0 No adhesions

1 Filmy adhesions, blunt dissection

2 Strong adhesions, sharp dissection

3 Very strong vascularized adhesions, sharp

dissection, damage hardly preventable

Figure 1 Peritoneal adhesion index: by ascribing to each abdomen area an adhesion related score as indicated, the sum of the scores will result in the PAI. 
adhesions, and visceral pain $[31,32]$. Currently, there is no effective method for preventing adhesion formation or reformation [33]. A more comprehensive understanding of the pathogenesis of adhesion formation at cellular and molecular levels is needed to streamline preventative treatment strategies [10].

The pathogenesis of adhesion formation involves three important trauma-induced processes: (I) inhibition of the fibrinolytic and extracellular matrix degradation systems [34,35]; (II) induction of an inflammatory response involving the production of cytokines and growth factor$\beta$ (TGF- $\beta 1$ ), a key regulator of tissue fibrosis [36-38]; and (III) induction of tissue hypoxia following interruption of blood delivery to mesothelial cells and submesothelial fibroblasts, leading to increased expression of hypoxia-induced factor- $1 \alpha[39,40]$ and vascular endothelial growth factor, responsible for collagen formation and angiogenesis $[31,41]$.

Several trials have examined the effects of systemic and local application of a variety of drugs, including steroids $[41,42]$, non-selective and selective cyclooxygenase inhibitors [43-47], heparin [48-50], 3-hydroxy-3-methylglutaryl-CoA reductase inhibitors (statins) [51], and tissue-plasminogen activator [52]. Different theoretical approaches involving, for example, growth factors or the neurokinin-1 receptor, have also been tested. Further, the use of natural agents such as pollen and honey or cold saline solutions has been explored in an effort to reduce adhesion rates $[53,54]$.

Local molecular therapies, including recombinant antibodies and protein, have been employed with moderate success [31]; these therapeutic agents work by correcting aberrant molecular pathways involved in adhesion formation [31]. Local molecular therapy is inherently limited; therefore an alternative strategy using gene therapy has recently been employed to correct molecular aberrations induced by surgical trauma [31]. In five studies based on rat models, different vectors were used to express therapeutic nucleic acids (transgenes or small interfering RNAs) in peritoneal tissue [31,40,55-59].

However, no method has distinguished itself as the optimal means of preventing adhesion formation [59]. Current preventive approaches range from the use of physical barriers to the administration of pharmacological agents, recombinant proteins and antibodies, and gene therapy, yet they have all failed to consistently yield satisfactory results. Single therapeutic strategies are typically unsuccessful in preventing peritoneal adhesions due to the multi-factorial nature of adhesion pathogenesis. Extensive literature on the subject demonstrates both the complexity of the issue and the myriad resources allocated to this condition, yet few interdisciplinary studies have been conducted involving experts from different fields. At this time the medical community only recognizes the "tip of the iceberg" and will continue treating the condition inadequately until it is more comprehensively explored.

We are in agreement with Hellebrekers et al. and believe that additional prospective studies must be conducted to examine adhesion formation in relation to factors of inflammation, coagulation, and fibrinolysis. To more effectively integrate the findings of different studies, specific attention should be paid to uniformity of measurement (what, where, and when to measure) [60]. We therefore suggest a regimented classification system for adhesions in an effort to standardize their definition and subsequent analysis. In this way, different surgeons in different treatment centers can more effectively evaluate patients and compare their conditions to past evaluations using a universal classification system (Figure 1). This classification is based on the macroscopic appearance of adhesions and their extent to the different regions of the abdomen. Using specific scoring criteria, clinicians can assign a peritoneal adhesion index (PAI) ranging from 0 to 30, thereby giving a precise description of the intra-abdominal condition. Standardized classification and quantification of adhesions would enable researchers to integrate the results of different studies to more comprehensively approach the treatment and management of adhesion-related pathology.

Furthermore, as asserted by other researchers [53], we must encourage greater collaboration among basic, material, and clinical sciences. Surgery is progressively becoming more dependent on the findings of research in the basic sciences, and surgeons must contribute by practicing research routinely in a clinical setting. To further advance surgical techniques, we must better understand the physiopathology of surgically induced conditions.

\section{Competing interests}

All authors declare to have no competing interests.

\section{Authors' contribution}

FCo, LA, FCa: Conception of the score, literature search and manuscript production. RM, LC, EP, PB, MS, SDS: literature search and analysis. MC, MGC, DL, MP: practical evaluation of the score. All authors read and approved the final manuscript.

\section{Author details}

${ }^{1}$ General and Emergency Surgery department, Papa Giovanni XXIII hospital, Piazza OMS-Organizzazione Mondiale della Sanità 1, 24128 Bergamo, Italy.

${ }^{2}$ General and Emergency Surgery department, Ospedale Maggiore, Parma, Italy. ${ }^{3}$ General Surgery department, Macerata Hospital, Macerata, Italy.

${ }^{4}$ General and Trauma Surgery department, Maggiore Hospital, Bologna, Italy.

Received: 17 July 2012 Accepted: 29 January 2013

Published: 31 January 2013

\section{References}

1. Diamond MP, Freeman ML: Clinical implications of postsurgical adhesions. Hum Reprod Update 2001, 7:567-576.

2. Arung W, Meurisse $M$, Detry O: Pathophysiology and prevention of postoperative peritoneal adhesions. World J Gastroenterol 2011, 17:4545-4553.

3. Sulaiman H, Gabella G, Davis MSc C, Mutsaers SE, Boulos P, Laurent GJ, Herrick SE: Presence and distribution of sensory nerve fibers in human peritoneal adhesions. Ann Surg 2001, 234:256-261. 
4. Ellis $\mathrm{H}$ : The clinical significance of adhesions: focus on intestinal obstruction. Eur J Surg Supp/ 1997, 577:5-9.

5. Pouly $J$, Seak-San S: Adhesions: laparoscopy versus laparotomy. In Peritoneal surgery. Edited by DiZerega GS. New York: Springer; 2000:183-192.

6. Diamond MP: Reduction of de novo postsurgical adhesions by intraoperative precoating with sepracoat (HAL-C) solution: a prospective, randomized, blinded, placebo-controlled multicenter study. The sepracoat adhesion study group. Fertil Steril 1998, 69:1067-1074.

7. Zühlke HV, Lorenz EM, Straub EM, Savvas V: Pathophysiology and classification of adhesions. Langenbecks Arch Chir Verh Dtsch Ges Chir 1990, Suppl 2:1009-1016.

8. Parker MC, Wilson MS, van Goor H, Moran BJ, Jeekel J, Duron JJ, Menzies D, Wexner SD, Ellis H: Adhesions and colorectal surgery - call for action. Colorectal Dis 2007, 9(Suppl 2):66-72.

9. Liakakos T, Thomakos N, Fine PM, Dervenis C, Young RL: Peritoneal adhesions: etiology, pathophysiology, and clinical significance. Recent advances in prevention and management. Dig Surg 2001, 18:260-273.

10. Cheong YC, Laird SM, Li TC, Shelton JB, Ledger WL, Cooke ID: Peritoneal healing and adhesion formation/reformation. Hum Reprod Update 2001 7:556-566.

11. Kössi J, Salminen P, Rantala A, Laato M: Population-based study of the surgical workload and economic impact of bowel obstruction caused by postoperative adhesions. Br J Surg 2003, 90:1441-1444.

12. Menzies $D$, Ellis $H$ : Intestinal obstruction from adhesions-how big is the problem? Ann R Coll Surg Engl 1990, 72:60-63.

13. Gutt CN, Oniu T, Schemmer P, Mehrabi A, Büchler MW: Fewer adhesions induced by laparoscopic surgery? Surg Endosc 2004, 18:898-906.

14. Krähenbühl L, Schäfer M, Kuzinkovas V, Renzulli P, Baer HU, Büchler MW: Experimental study of adhesion formation in open and laparoscopic fundoplication. Br J Surg 1998, 85:826-830.

15. Garrard CL, Clements RH, Nanney L, Davidson JM, Richards WO: Adhesion formation is reduced after laparoscopic surgery. Surg Endosc 1999, 13:10-13.

16. Polymeneas G, Theodosopoulos T, Stamatiadis A, Kourias E: A comparative study of postoperative adhesion formation after laparoscopic vs open cholecystectomy. Surg Endosc 2001, 15:41-43.

17. Molinaro F, Kaselas C, Lacreuse I, Moog R, Becmeur F: Postoperative intestinal obstruction after laparoscopic versus open surgery in the pediatric population: A 15-year review. Eur J Pediatr Surg 2009, 19:160-162.

18. Dijkstra FR, Nieuwenhuijzen M, Reijnen MM, van Goor H: Recent clinical developments in pathophysiology, epidemiology, diagnosis and treatment of intra-abdominal adhesions. Scand J Gastroenterol Supp/2000, 232:52-59.

19. Al-Jaroudi $D$, Tulandi T: Adhesion prevention in gynecologic surgery. Obstet Gynecol Surv 2004, 59:360-367.

20. Alpay Z, Saed GM, Diamond MP: Female infertility and free radicals: potential role in adhesions and endometriosis. J Soc Gynecol Investig 2006, 13:390-398.

21. Trimbos-Kemper TC, Trimbos JB, van Hall EV: Adhesion formation after tubal surgery: results of the eighth-day laparoscopy in 188 patients. Fertil Steril 1985, 43:395-400.

22. Kresch AJ, Seifer DB, Sachs LB, Barrese I: Laparoscopy in 100 women with chronic pelvic pain. Obstet Gynecol 1984, 64:672-674.

23. Sutton C, MacDonald R: Laser laparoscopic adhesiolysis. J Gynecol Surg 1990, 6:155-159.

24. Ellis H, Moran BJ, Thompson JN, Parker MC, Wilson MS, Menzies D, McGuire A, Lower AM, Hawthorn RJ, O'Brien F, Buchan S, Crowe AM: Adhesion-related hospital readmissions after abdominal and pelvic surgery: a retrospective cohort study. Lancet 1999, 353:1476-1480.

25. Diamond MP, Wexner SD, DiZerega GS, et al: Adhesion prevention and reduction: current status and future recommendations of a multinationalinter-disciplinary consensus conference. Surg Innov 2012 17:183-188.

26. McEntee G, Pender D, Mulvin D, McCullough M, Naeeder S, Farah S, Badurdeen MS, Ferraro V, Cham C, Gillham N: Current spectrum of intestinal obstruction. Br J Surg 1987, 74:976-980.

27. Prushik SG, Stucchi AF, Matteotti R, Aarons CB, Reed KL, Gower AC, Becker JM: Open adhesiolysis is more effective in reducing adhesion reformation than laparoscopic adhesiolysis in an experimental model. Br J Surg 2010, 97:420-427.

28. Catena F, Di Saverio S, Kelly MD, Biffl WL, Ansaloni L, Mandalà V, et al: Bologna guidelines for diagnosis and management of adhesive small bowel obstruction (ASBO): 2010 evidence-based guidelines of the world society of emergency surgery. World J Emerg Surg 2011, 6:5. 21

29. Ray NF, Larsen JW, Stillman RJ, Jacobs RJ: Economic impact of hospitalizations for lower abdominal adhesiolysis in the United States in 1988. Surg Gynecol Obstet 1993, 176:271-276.

30. Ray NF, Denton WG, Thamer M, Henderson SC, Perry S: Abdominal adhesiolysis: inpatient care and expenditures in the United States in 1994. J Am Coll Surg 1998, 186:1-9.

31. Atta MH: Prevention of peritoneal adhesions: a promising role for gene therapy. World J Gastroenterol 2011, 17:5049-5058.

32. Ellis $H$, Crowe A: Medico-legal consequences of post-operative intra-abdominal adhesions. Int J Surg 2009, 7:187-191.

33. Wiseman DM, Trout JR, Diamond MP: The rates of adhesion adhesion development and the effects of crystalloid solutions on adhesion development in pelvic surgery. Fertil Steril 1998, 70:702-711.

34. Holmdahl L, Eriksson E, Eriksson Bl, Risberg B: Depression of peritoneal fibrinolysis during operation is a local response to trauma. Surgery 1998 123:539-544.

35. Ivarsson ML, Bergström M, Eriksson E, Risberg B, Holmdahl L: Tissue markers as predictors of postoperative adhesions. Br J Surg 1998, 85:1549-1554

36. Holmdahl L, Kotseos K, Bergström M, Falk P, Ivarsson ML, Chegini N: Overproduction of transforming growth factorbeta1 (TGF-beta1) is associated with adhesion formation and peritoneal fibrinolytic impairment. Surgery 2001, 129:626-632.

37. Chegini N, Kotseos K, Zhao Y, Bennett B, McLean FW, Diamond MP, Holmdahl L, Burns J: Differential expression of TGF-beta1 and TGF-beta3 in serosal tissues of human intraperitoneal organs and peritoneal adhesions. Hum Reprod 2001, 16:1291-1300.

38. Cheong YC, Shelton JB, Laird SM, Li TC, Ledger WL, Cooke ID: Peritoneal fluid concentrations of matrix metalloproteinase- 9, tissue inhibitor of metalloproteinase-1, and transforming growth factor-beta in women with pelvic adhesions. Fertil Steril 2003, 79:1168-1175.

39. Molinas CR, Campo R, Elkelani OA, Binda MM, Carmeliet P, Koninckx PR: Role of hypoxia inducible factors 1alpha and 2alpha in basal adhesion formation and in carbon dioxide pneumoperitoneum-enhanced adhesion formation after laparoscopic surgery in transgenic mice. Fertil Steril 2003, 80(Suppl 2):795-802.

40. Segura T, Schmokel H, Hubbell JA: RNA interference targeting hypoxia inducible factor 1 alpha reduces post-operative adhesions in rats. J Surg Res 2007, 141:162-170.

41. Cahill RA, Wang JH, Soohkai S, Redmond HP: Mast cells facilitate local VEGF release as an early event in the pathogenesis of postoperative peritoneal adhesions. Surgery 2006, 140:108-112.

42. Avsar FM, Sahin M, Aksoy F, Avsar AF, Akoz M, Hengirmen S, Bilici S: Effects of diphenhydramine $\mathrm{HCl}$ and methylprednisolone in the prevention of abdominal adhesions. Am J Surg 2001, 181(6):512-515.

43. Sahin M, Cakir M, Avsar FM, Tekin A, Kucukkartallar T, Akoz M: The effects of anti-adhesion materials in preventing postoperative adhesion in abdominal cavity (anti-adhesion materials for postoperative adhesions). Inflammation 2007, 30(6):244-249.

44. Muzii L, Marana R, Brunetti L, Margutti F, Vacca M, Mancuso S: Postoperative adhesion prevention with low-dose aspirin: effect through the selective inhibition of thromboxane production. Hum Reprod 1998, 13(6):1486-1489.

45. Oh SH, Kim JK, Song KS, Noh SM, Ghil SH, Yuk SH, Lee JH: Prevention of postsurgical tissue adhesion by anti-inflammatory drug-loaded pluronic mixtures with sol-gel transition behavior. J Biomed Mater Res A 2005 72(3):306-316

46. Rodgers KE, Johns DB, Girgis W, diZerega GS: Prevention of adhesion formation with intraperitoneal administration of tolmetin and hyaluronic acid. J Invest Surg 1997, 10(6):367-373.

47. Aldemir M, Ozturk $H$, Erten C, Buyukbayram H: The preventive effect of rofecoxib in postoperative Intraperitoneal adhesions. Acta Chir Belg 2004, 104(1):97-100

48. Fukasawa M, Girgis W, diZerega GS: Inhibition of postsurgical adhesions in a standardized rabbit model: II. Intraperitoneal treatment with heparin. Int J Fertil 1991, 36(5):296-301.

49. Kutlay J, Ozer Y, Isik B, Kargici H: Comparative effectiveness of several agents for preventing postoperative adhesions. World J Surg 2004, 28(7):662-665.

50. Parsak CK, Satar S, Akcam T, Satar D, Sungur I: Effectiveness of treatment to prevent adhesions after abdominal surgery: an experimental evaluation in rats. Adv Ther 2007, 24(4):796-802 
51. Aarons $C B$, Cohen PA, Gower A, Reed KL, Leeman SE, Stucchi AF, et al: Statins (HMG-CoA reductase inhibitors) decrease postoperative adhesions by increasing peritoneal fibrinolytic activity. Ann Surg 2007, 245:176-184.

52. Dorr PJ, Vemer HM, Brommer EJ, Willemsen WN, Veldhuizen RW, Rolland R: Prevention of postoperative adhesions by tissuetype plasminogen activator (t-PA) in the rabbit. Eur J Obstet Gynecol Reprod Biol 1990, 37(3):287-291.

53. Celeplı S, Kismet K, Kaptanoğlu B, Erel S, Ozer S, Celeplı P, et al: The effect of oral honey and pollen on postoperative intraabdominal adhesions. Turk J Gastroenterol 2011, 22:65-72.

54. Fang CC, Chou TH, Lin GS, Yen ZS, Lee CC, Chen SC: Peritoneal infusion with cold saline decreased postoperative intra-abdominal adhesion formation. World J Surg 2010, 34:721-727.

55. Atta HM, Al-Hendy A, El-Rehany MA, Dewerchin M, Abdel Raheim SR, Abdel Ghany H, Fouad R: Adenovirusmediated overexpression of human tissue plasminogen activator prevents peritoneal adhesion formation/ reformation in rats. Surgery 2009, 146:12-17.

56. Guo H, Leung JC, Cheung JS, Chan LY, Wu EX, Lai KN: Non-viral Smad7 gene delivery and attenuation of postoperative peritoneal adhesion in an experimental model. Br J Surg 2009, 96:1323-1335.

57. Guo Q, Li QF, Liu HJ, Li R, Wu CT, Wang LS: Sphingosine kinase 1 gene transfer reduces postoperative peritoneal adhesion in an experimental model. Br J Surg 2008, 95:252-258.

58. Liu HJ, Wu CT, Duan HF, Wu B, Lu ZZ, Wang L: Adenoviral- mediated gene expression of hepatocyte growth factor prevents postoperative peritoneal adhesion in a rat model. Surgery 2006, 140:441-447.

59. Brochhausen C, Schmitt VH, Planck CN, Rajab TK, Hollemann D, Tapprich C, et al: Current strategies and future perspectives for Intraperitoneal adhesion prevention. J Gastrointest Surg 2012, Epub ahead of print.

60. Hellebrekers BW, Kooistra T: Pathogenesis of postoperative adhesion formation. Br J Surg 2011, 98:1503-1516.

doi:10.1186/1749-7922-8-6

Cite this article as: Coccolini et al:: Peritoneal adhesion index (PAl): proposal of a score for the "ignored iceberg" of medicine and surgery. World Journal of Emergency Surgery 2013 8:6.

\section{Submit your next manuscript to BioMed Central and take full advantage of:}

- Convenient online submission

- Thorough peer review

- No space constraints or color figure charges

- Immediate publication on acceptance

- Inclusion in PubMed, CAS, Scopus and Google Scholar

- Research which is freely available for redistribution 